\title{
HUBUNGAN PENGETAHUAN DAN PERILAKU ORANGTUA DALAM MEMELIHARA KESEHATAN GIGI DENGAN KARIES GIGI PADA ANAK TAMAN KANAK KANAK
}

\author{
RELATIONSHIPS TO KNOWLEDGE AND BEHAVIOR OF PARENTS IN \\ MAINTAINING DENTAL HEALTH WITH DENTAL CARE IN KINDERGARTEN
}

\author{
Rasuna Ulfah ${ }^{1 *}$, Naning Kisworo Utami ${ }^{2}$ \\ 1,2 Jurusan Keperawatan Gigi Poltekkes Kemenkes Banjarmasin \\ Jalan garuda No.21 Banjarbaru, Kalimantan Selatan. Indonesia \\ *Email: rasunaulfah82@gmail.com
}

\begin{abstract}
Caries is a disease of dental hard tissue, namely enamel, dentin and cementum, which is caused by the activity of a microorganism in a distributed carbohydrate. The role of parents is needed to guide children in terms of maintaining oral health, this means that parental knowledge and behavior can affect the oral health of preschool children. This study aims to determine the relationship between parental knowledge and behavior with dental caries in TK Pertiwi Simpang Empat Banjar Regency. This research is analytic with cross sectional design, with the research population of all children in TK Pertiwi Simpang Empat, Banjar Regency. The sample consisted of 60 children aged 5 to 6 years. Data were collected by examining dental caries in children and distributing questionnaires to the child's parents. The results showed the knowledge of parents with child dental caries was 0,000 $(p=0,000)$, with a significance level of $5 \%(0,05)$ so that $p<0,05$ and the behavior of parents with child dental caries was $0,000(p=0,000)$, with a significance level of $5 \%(0,05)$ up to ap $<0,05$. In this study, it can be concluded that there is a relationship between parental knowledge and children's dental caries and there is a relationship between parental behavior and children's dental caries. It is suggested to do dental and oral health education to parents so that it is hoped that it can increase public knowledge and awareness in maintaining oral health.
\end{abstract}

Keywords: Knowledge; Behavior; Parents; Dental Caries

\begin{abstract}
ABSTRAK
Karies merupakan suatu penyakit jaringan keras gigi, yaitu email, dentin dan sementum, yang disebabkan oleh aktifitas suatu jasad renik dalam suatu karbohidrat yang diragikan. Peran orangtua sangat diperlukan untuk membimbing anak dalam hal pemeliharaan kesehatan gigi dan mulut, ini berarti pengetahuan dan perilaku orangtua dapat mempengaruhi kesehatan gigi dan mulut anak prasekolah. Penelitian ini bertujuan ini untuk mengetahui hubungan antara pengetahuan dan perilaku orangtua dengan karies gigi pada anak TK Pertiwi Simpang Empat Kabupaten Banjar. Penelitian ini bersifat analitik dengan rancangan cross sectional,dengan populasi penelitian seluruh anak di TK Pertiwi Simpang Empat Kabupaten Banjar. Sampel berjumlah 60 anak yang berusia 5 sampai 6 tahun. Data diambil dengan cara pemeriksaan karies gigi pada anak serta pembagian daftar pertanyaan (kuesioner) pada orangtua anak. Hasil penelitian menunjukkan pengetahuan orangtua dengan karies gigi anak yaitu $0,000(p=0,000)$, dengan tingkat kemaknaan $5 \%(0,05)$ sehingga $\mathrm{p}<0,05$ dan perilaku orangtua dengan karies gigi anak yaitu $0,000(\mathrm{p}=0,000)$, dengan tingkat kemaknaan $5 \%(0,05)$ sehingg a $\mathrm{p}<0,05$. Pada penelitian ini dapat disimpulkan bahwa ada hubungan antara pengetahuan orangtua dengan karies gigi anak dan ada hubungan antara perilaku orangtua dengan karies gigi anak. Disarankan untuk dilakukan penyuluhan kesehatan gigi dan mulut pada orang tua sehingga diharapkan dapat meningkatkan pengetahuan dan kesadaran masyarakat dalam memelihara kesehatan gigi dan mulut.
\end{abstract}

Kata Kunci: Pengetahuan; Perilaku; Orangtua; Karies Gigi 


\section{PENDAHULUAN}

Kerusakan gigi mempengaruhi lebih dari $70 \%$ anak sekolah di seluruh dunia. Kerusakan gigi pada anak-anak dapat menyebabkan rasa sakit, sehingga mempengaruhi nafsu makan dan asupan nutrisi, yang pada akhirnya mempengaruhi status gizi anak dan berdampak negatif pada kualitas hidup anak-anak (1). Penduduk yang bermasalah gigi dan mulut di Kabupaten Banjar adalah sebesar 48,6\%, jauh berada diatas rata-rata angka Nasional yaitu 25,9\% dan berada di urutan tertinggi di Kalimantan Selatan. Penduduk yang bermasalah gigi dan mulut tertinggi berada pada kelompok umur 5-9 tahun sebesar 43,2\%. Rata-rata penduduk Kabupaten Banjar berperilaku benar dalam menyikat gigi yang benar hanya 3,1\% (2).

Keluarga sebagai unit budaya mempengaruhi sikap dan kepercayaan anggotanya. Kelonggaran orang tua saat mengatur konsumsi gula merupakan faktor yang sangat signifikan mempengaruhi status karies mereka. Kebiasaan anak-anak yang didapat pada awal kehidupan terus membentuk sikap dan pilihan gaya hidup yang akan mereka gunakan sampai dewasa. Kebersihan mulut dan kebiasaan makan yang baik diadopsi pada usia dini dan akan berdampak pada kesehatan mulut yang baik pada saat dewasa. Kebiasaan ini sebagian besar diperoleh melalui pembelajaran dan observasional terutama orang tua dan keluarga terdekat (3). Pada anak-anak, pengaruh dari orang tua sangat kuat. Sikap dan perilaku orang tua terutama ibu dalam pemeliharaan gigi memberi pengaruh yang cukup signifikan terhadap sikap dan perilaku anak (4).

Penelitian Afiati et al., (5) menyatakan bahwa tingkat pengetahuan ibu mempengaruhi perilaku pemeliharaan kesehatan gigi pada anak-anak dan tingkat pengetahuan ibu yang rendah berhubungan dengan prevalensi karies gigi yang tinggi. Penelitian Sarmento et al., (6) menyatakan pengetahuan orang tua tentang perilaku kesehatan dapat meningkatkan kemampuan mereka untuk mengawasi anakanaknya dalam menjaga kebersihan gigi dan mulutnya. Kurangnya pengetahuan orang tua mengenai pengaruh diet tehadap perkembangan karies gigi, meningkatkan pemberian makanan manis pada anak-anak mereka, sehingga anak-anak lebih sering terpapar faktor risiko karies gigi.

\section{BAHAN DAN METODE}

Jenis penelitian adalah penelitian survey analitik. Survei analitik adalah menggali bagaimana dan mengapa fenomena kesehatan itu terjadi. Kemudian melakukan analisis dinamika kolerasi antara faktor resiko dengan faktor efek (7). Rancangan penelitian yang digunakan adalah penelitian survey analitik dengan pendekatan cross sectional. Populasi pada penelitian ini adalah orang tua yang memiliki anak di TK Pertiwi Kecamatan Simpang Empat Kabupaten Banjar. Pengumpulan data primer dilakukan dengan cara melakukan pemeriksaan langsung di Taman Kanak-Kanak Pertiwi Simpang Empat yang ditetapkan sebagai sampel dengan menggunakan format pemeriksaan untuk mencatat angka karies serta memberikan daftar pertanyaan (kuesioner) pada orang tua murid tentang pengetahuan dan perilaku orang tua dalam memelihara kesehatan gigi anak. Data dari penelitian ini disajikan dalam bentuk tabel distribusi frekuensi dengan prosentase. Dari pengolahan data dilakukan analisis data dengan uji statistiks Chi square test (8).

\section{HASIL DAN PEMBAHASAN}

\section{Analisis Univariat}

Tabel 1. Distribusi Frekuensi Karies Gigi Pada Anak TK, Pengetahuan Orang Tua dan Perilaku Orang Tua Dalam Memelihara Kesehatan Gigi Pada Anak TK Pertiwi Simpang Empat Kabupaten Banjar

\begin{tabular}{lcc}
\hline \multicolumn{1}{c}{ Variabel } & $\mathrm{n}$ & $\%$ \\
\hline Karies & 51 & 85 \\
Karies & 9 & 15 \\
Tidak Karies & & \\
$\begin{array}{l}\text { Pengetahuan Orang Tua } \\
\text { Dalam Memelihara Kesehatan }\end{array}$ & & \\
Gigi & 21 & 35 \\
$\begin{array}{l}\text { Pengetahuan Orang Tua Baik } \\
\text { Pengetahuan Orang Tua }\end{array}$ & 39 & 65 \\
$\begin{array}{l}\text { Kurang Baik } \\
\text { Perilaku Orang Tua Dalam }\end{array}$ & & \\
$\begin{array}{l}\text { Memelihara Kesehatan Gigi } \\
\text { Perilaku Orang Tua Baik }\end{array}$ & 16 & 26,7 \\
$\begin{array}{l}\text { Perilaku Orang Tua Kurang } \\
\text { baik }\end{array}$ & 44 & 73,3 \\
\hline Jumlah & 60 & 100 \\
\hline
\end{tabular}


Berdasarkan tabel 1 dapat dilihat dalam variabel karies gigi, bahwa dari 60 responden terdapat 51 responden (85\%) mengalami karies gigi dan 9 responden $(15 \%)$ yang tidak mengalami karies gigi. Variabel pengetahuan orang tua, bahwa dari 60 responden terdapat 21 responden (35\%) memiliki pengetahuan baik dan 39 responden $(65 \%)$ orangtua yang memiliki pengetahuan dengan kategori kurang baik dalam memelihara kesehatan gigi. adalah sebanyak 39 responden g (65\%). Variabel perilaku orang tua, bahwa dari 60 orang tua terdapat 16 responden $(26,7 \%)$, dan 44 responden $(73,3 \%)$ orang tua yang memiliki perilaku yang kurang baik dalam memelihara kesehatan gigi.

\section{Analisis Bivariat}

Tabel 2 Hubungan Faktor Pengetahuan dan Perilaku Orang Tua Dalam Memelihara Kesehatan Gigi Dengan Karies Gigi Pada Anak Taman Kanak-Kanak

\begin{tabular}{|c|c|c|c|c|c|c|c|}
\hline \multirow{3}{*}{ Variabel } & \multicolumn{4}{|c|}{ Karies Giigi } & \multirow{3}{*}{$\mathbf{N}$} & \multirow{3}{*}{$\%$} & \multirow{3}{*}{ P-Value } \\
\hline & \multicolumn{2}{|c|}{ Tidak Karies } & \multicolumn{2}{|c|}{ Karies } & & & \\
\hline & $\mathbf{n}$ & $\%$ & $\mathbf{n}$ & $\%$ & & & \\
\hline \multicolumn{8}{|c|}{ Pengetahuan Orang Tua } \\
\hline Baik & 9 & 15 & 12 & 20 & 21 & 35 & 0,000 \\
\hline Kurang & 0 & 0 & 39 & 65 & 39 & 65 & \\
\hline \multicolumn{8}{|l|}{ Perilaku Orang Tua } \\
\hline Baik & 8 & 13,3 & 8 & 13,3 & 16 & 26,6 & 0,000 \\
\hline Kurang & 1 & 1,7 & 43 & 71,7 & 44 & 73,4 & \\
\hline
\end{tabular}

\section{Hubungan Pengetahuan Orang Tua Dengan Karies Gigi Pada Anak Taman Kanak-Kanak}

Berdasarkan hasil penelitian didapatkan tingginya anak yang mengalami karies gigi di TK Pertiwi Kabupaten Banjar yaitu sebesar 85\%. Penelitian ini sejalan dengan penelitian Sukarsih (9) pada TK Al Hikmah Jambi dimana didapatkan 96,7\% anak TK mengalami karies gigi. Anak-anak adalah kelompok yang rentan terhadap penyakit gigi dan mulut. Karena pada usia tersebut anak-anak sangat menyukai makanan manis dan kebersihan mulut yang kurang terjaga (10).

Hasil penelitian menunjukkan orang tua yang memiliki pengetahuan yang kurang baik dalam memelihara kesehatan gigi memiliki anak yang mengalami karies gigi sebanyak $65 \%$. Hasil analisa statistik menunjukkan adanya hubungan antara pengetahuan orang tua dalam memelihara kesehatan gigi dan mulut denga karies gigi pada anak TK Pertiwi Simpang Empat Kabupaten Banjar ( $p$ value $0,000)$. Penelitian yang sama juga didapatkan pada penelitian Setyaningsih dan Prakoso (11) menyatakan ada hubungan signifikan antara pengetahuan orang tua dengan kejadian karies gigi pada anak usia balita di desa Mancasan Baki Sukoharjo. Orang tua yang memiliki tingkat pengetahuan yang tinggi tentang kesehatan gigi mampu mencegah anak balitanya mengalami karies gigi 11 kali lebih baik daripada orang tua yang memiliki tingkat pengetahuan rendah. Hasil penelitian ini sejalan dengan penelitian Sari (12) tentang hubungan pengetahuan ibu dengan kejadian karies gigi pada anak didesa Banjar Negeri kecamatan Way Lima Kabupaten Pesawaran diperoleh hasil nilai $p=0,029 \leq 0,05$, maka disimpulkan ada hubungan antara pengetahuan ibu tentang kesehatan gigi dengan kejadian karies gigi pada anak .

Hasil penelitian yang sama juga didapatkan pada penelitian Chen et al., (13) juga menyatakan prevalensi karies gigi yang lebih tinggi ditemukan pada anak-anak yang memiliki orang tua dengan tingkat pengetahuan yang rendah dibandingkan dengan anak-anak yang memilki orang tua dengan tingkat pengetahuan yang tinggi. Hasil penelitian Afiati (5) menyatakan semakin tinggi pengetahuan ibu maka semakin rendah indeks karies gigi anak dengan nilai $p=0,001$. Peran orang tua memegang peranan penting dalam mendidik dan membina anak dalam memelihara kesehatan giginya. Seseorang yang memiliki tingkat pengetahuan yang tinggi akan mempengaruhi perilakunya untuk hidup sehat. Peranan ibu dalam keluarga adalah sebagai 
pemimpin kesehatan dan pemberi asuhan. Berdasarkan peranan tersebut seorang ibu harus mengetahui berbagai hal tentang kesehatan gigi dan mulut. dalam perawatan kesehatan gigi, anak perlu diajari ibu cara menyikat gigi dimulai saat usia 2 tahun. Pemberian edukasi mengenai pentingnya perawatan kesehatan gigi pun sebaiknya diberikan kepada anak untuk menyikat gigi minimal dua kali sehari yaitu pada pagi hari sesudah sarapan dan sebelum tidur malam (3). Pengetahuan orang tua tentang kesehatan gigi sangat penting dalam mendasari terbentuknya perilaku yang mendukung atau tidak mendukung kebersihan gigi dan mulut pada anak. Pendidikan kesehatan gigi yang disampaikan kepada masyarakat diharapkan akan mampu mengubah perilaku yang tidak sehat menuju sehat, sehingga peranan ibu dalam merawat kesehatan gigi anak dapat mempengaruhi status karies gigi anak (4). Tingkat pengetahuan ibu yang tinggi tentang perilaku kesehatan gigi dan mulut berhubungan dengan perilaku anak dalam menjaga kebersihan giginya (11). Pengetahuan orang tua yang kurang tentang kesehatan mulut berhubungan dengan perilaku kesehatan anak yang rendah dalam memelihara kebersihan gigi dan berdampak buruk pada kesehatan gigi anak (14).

\section{Hubungan Perilaku Orang Tua Dengan Karies Gigi Pada Anak Taman Kanak-Kanak}

Hasil penelitian menunjukkan perilaku orang tua yang kurang baik dalam memelihara kesehatan gigi memiliki anak yang mengalami karies gigi sebesar $73,4 \%$. Hasil analisis menunjukan adanya hubungan antara pengetahuan orang tua dalam memelihara kesehatan gigi dengan karies gigi pada anak TK Pertiwi Simpang empat Kabupaten Banjar ( $p$ value $0,000)$. Hasil penelitian yang sama juga didapatkan pada penelitian Jyot et al., (15), dimana terdapat hubungan. Penelitian Angelica et al., (16) juga memperoleh hasil yang sama dimana terdapat pengaruh perilaku ibu terhadap indeks def-t pada anak usia 4-5 tahun di TK Santa Maria Kota Cirebon. Perilaku orangtua yang mengabaikan kesehatan gigi dan mulut anaknya, berdampak pada prevalensi karies yang tinggi pada anaknya. Perilaku orang tua dalam pemanfaatan pelayanan kesehatan gigi anak berpengaruh positif terhadap risiko terjadinya karies gigi pada anak, karena anak- anak masih mempunyai sikap ketergantungan pada pada orang tua terutama ibu yang paling berperan dalam menjaga kesehatan gigi anaknya (17). Faktor yang juga mempengaruhi anak mengalami karies gigi antara lain kebersihan rongga mulut, dan pola makan anak. Kebersihan rongga mulut sangat mempengaruhi tinggi rendahnya karies gigi pada anak, sehingga perilaku ibu sangat dibutuhkan dalam mengawasi dan mengajarkan anak untuk memelihara kesehatan gigi anaknya. Menjaga kebersihan gigi dan mulut anak adalah hal yang sangat penting untuk menurunkan angka karies gigi pada anak Pra Sekolah (18).

\section{KESIMPULAN DAN SARAN}

Berdasarkan hasil penelitian maka dapat disimpulkan bahwa ada hubungan pengetahuan dan perilaku orangtua dalam memelihara kesehatan gigi dengan karies gigi pada anak TK Pertiwi Simpang Empat Kabupaten Banjar. Disarankan untuk dilakukan penyuluhan kesehatan gigi dan mulut pada orang tua sehingga diharapkan dapat meningkatkan pengetahuan dan kesadaran masyarakat dalam memelihara kesehatan gigi dan mulut.

\section{UCAPAN TERIMAKASIH}

Ucapan terima kasih kepada rekan dan pihak yang membantu penelitian ini, terutama kepada TK Pertiwi Kabupaten Banjar yang telah memberi ijin untuk tempat penelitian ini.

\section{DAFTAR PUSTAKA}

1. WHO. World Health Organization. 2013.

2. Riskesdas. Riset Kesehatan Dasar. Kemenkes RI. 2013.

3. Sujlana A, Pannu PK. Family Related Factorc Associated with Caries prevalence in the Primary Dentition of Five-year-old Children. Journal of Indian Society of Pedodontics and Preventive Dentistry. 2015, 33 (2): 83-87.

4. Eddy FNE, Mutiara H. Peranan Ibu dalam Pemeliharaan Kesehatan Gigi Anak dengan Status Karies Anak Usia Sekolah Dasar. Jurnal Majority. 2015; 4(8): 1-6.

5. Afiati R, Adhani R, Ramadhani K, Diana S. Hubungan Perilaku Ibu Tentang Pemeliharaan Kesehatan Gigi dan Mulut Terhadap Status Karies Gigi Anak : Tinjauan Berdasarkan 
Pengetahuan, Tingkat Pendidikan dan Status Sosial di TK ABA 1 Banjarmasin. Dentino Jurnal Kedokteran Gigi. 2017; 2 (1): 56-62.

6. Sarmento TCAP, Abreu MH, Gomes MC, Costa EMMB, Martins CC, Garcia AFG, Palva SM. Determinant Factors of Untreated Dental Caries and Lesion Activity in Preschool Children Using ICDAS. Journal Pone. 2016;10: 1-11

7. Notoatmodjo S. Metodologi Penelitian Kesehatan. Jakarta : Rineka Cipta; 2012.

8. Dahlan MS. Statistik untuk Kedokteran dan Kesehatan, Jakarta: Salemba Medika; 2009.

9. Sukarsih, Silfia A, Febrianti S. Hubungan Pengetahuan Ibu Tentang Pemeliharaan Kesehatan Gigi Dengan Status Karies Pada Anak Tk Al-Hikmah Kota Jambi Tahun 2018. Jurnal Bahan Kesehatan Masyarakat. 2018; 2 (2).

10. Thyath MN, Nishad SG, Sharma M, Zaidi I. Impact of Socioeconomic Status and Parental Factors On Child Oral Health A Review of Literature. Journal of Advanced Medical and Dental Science Research. 2015;3(2): 153-157.

11. Setyaningsih R, Prakoso I. Hubungan Tingkat Pendidikan, Tingkat Sosial Ekonomi dan Tingkat Pengetahuan Orang Tua Tentang Perawatan Gigi dengan Kejadian Karies Gigi Anak Usia Balita di Desa Mancasan Baki Sukoharjo. Jurnal Kosala. 2016; 4 (1): 13-24.

12. Sari R. Hubungan Pengetahuan Ibu dengan Kejadian Karies Gigi pada Anak di Desa Banjar Negeri Kecamatan Way Lima Kabupaten Pesawaran. Jurnal Wacana Kesehatan. 2016; 1(1): 22-27.

13. Chen KJ, Gao SS, Duangthip D, Li SK, Lo ECM, $\mathrm{Chu} \mathrm{CH}$. Dental Caries Status and its Associated Factors Among 5-Year-Old Hongkong Children: a Cross sectional Study. BMC Oral Health. 2017; 17: $1-8$.

14. Ramirez ME, Burgos LA, Santilan ES, Ayala FA, Carrilo EL, Sancez M, Rodriguez, MM, Corona MLM, Solis CEM. Factor Associated with Dental Plain in Mexican Schoolchildren aged to 12 years, Biomed Reseach International. 2017; 10: 1-10.

15. Jyoti NPCP, Giri PRK, Handoko SA, Kurniati DPY, Rahaswanti LWA. Hubungan Tingkat Pengetahuan Dan Perilaku Ibu Dalam Merawat Gigi Anak Terhadap Kejadian Karies Anak di TK Titi Dharma Denpasar. Bali Dental Journal. 2019; 3(2): 96-102.
16. Angelica C, Sembiring LS, Suwindere W. Pengaruh Tingkat Pendidikan Tinggi Dan Perilaku Ibu Terhadap Indeks def-T Pada Anak Usia 4-5 Tahun. J Dent Res Student. 2019; 3(1):2025.

17. Undang- undang Republik Indonesia Nomor 20 Tahun 2003 Tentang Sistem Pendidikan Nasional.

18. Mentari S, Bany ZU, Novita CF. Hubungan Peran Orang Tua Terhadap Indeks DMF-T Siswa Sekolah Dasar Dengan UKGS. J Caninus Dent. 2016; 1(4):63-69Putro PJS, Suprihatin. Pola diet tepat jumlah, jadwal, dan jenis terhadap kadar gula darah pasien diabetes mellitus tipe 2, Jurnal STIKES volume 5, No.1; 2012. 